\title{
Mapping Quantitative Trait Loci for Seizure Response to a GABA Receptor Inverse Agonist in Mice
}

\author{
Howard K. Gershenfeld,, ${ }^{1}$ Paul E. Neumann, ${ }^{2}$ Xiaohua Li, ${ }^{1}$ Pamela L. St. Jean, ${ }^{3}$ and Steven M. Paul| ${ }^{4,5}$ \\ ${ }^{1}$ Department of Psychiatry, University of Texas Southwestern Medical Center, Dallas, Texas 75235-8898, ${ }^{2}$ Department of \\ Anatomy and Neurobiology, Dalhousie University, Halifax, Nova Scotia, Canada B3H 4H7, ${ }^{3}$ Glaxo Wellcome Research, \\ Inc., Research Triangle Park, North Carolina 27514, ${ }^{4}$ Lilly Research Laboratory, Indianapolis, Indiana 46285, and \\ ${ }^{5}$ Departments of Psychiatry, Pharmacology and Toxicology, Indiana University School of Medicine, \\ Indianapolis, Indiana 46202
}

To define the genetic contributions affecting individual differences in seizure threshold, a $\beta$ carboline [methyl- $\beta$-carboline3-carboxylate $(\beta$-CCM)]-induced model of generalized seizures was genetically dissected in mice. $\beta-C C M$ is a GABA $\mathrm{A}_{\mathrm{A}}$ receptor inverse agonist and convulsant. By measuring the latency to generalized seizures after $\beta-\mathrm{CCM}$ administration to $\mathrm{A} / \mathrm{J}$ and C57BL6/J mice and their progeny, we estimated a heritability of $0.28 \pm 0.10$. A genome wide screen in an F2 population of these parental strains $(n=273)$ mapped quantitative trait loci (QTLs) on proximal chromosome 7 [logarithm of the likelihood for linkage $(L O D)=3.71]$ and distal chromosome 10 (LOD = 4.29) for seizure susceptibility, explaining $\sim 22$ and $25 \%$, respectively, of the genetic variance for this seizure trait. The best fitting logistic regression model suggests that the $\mathrm{A} / \mathrm{J}$ allele at each locus increases the likelihood of seizures approximately threefold. In a subsequent backcross population $(n=223)$, we mapped QTLs on distal chromosome $4(\mathrm{LOD}=2.88)$ and confirmed the distal chromosome 10 QTLs (LOD = 4.36). In the backcross, the C57BL/6J allele of the chromosome 10 QTL decreases the risk of seizures approximately twofold. These QTLs may ultimately lead to the identification of genes influencing individual differences in seizure threshold in mice and the discovery of novel anticonvulsant agents. The colocalization on distal chromosome 10 of a $\beta$-CCM susceptibility QTL and a QTL for open field ambulation and vertical movement suggests the existence of a single, pleiotropic locus, which we have named Exq1.

Key words: quantitative trait locus (QTL); epilepsy; seizure; $\beta$-carboline; open field; individual differences
Wide inter-individual differences ( $\sim 12$-fold $)$ in seizure thresholds have been documented in humans as measured by the electrical stimulus dose needed to induce a seizure (Sackeim et al., 1991; Colenda and McCall, 1996). Despite intense investigations at the molecular, cellular, neural network, slice, and whole-brain levels (McNamara, 1992, 1994), the pathophysiology of paroxysmal discharges and seizure threshold regulation are incompletely understood. Genetic factors contribute to a predisposition for seizures with a complex inheritance (Anderson et al., 1986; Berkovic et al., 1998). Recent conflicting results in mapping loci for juvenile myoclonic epilepsy (Greenberg and Delgado-Escueta, 1993; Liu et al., 1995, 1996; Elmslie et al., 1996; Serratosa et al., 1996) have highlighted the problems in mapping loci for complex diseases such as epilepsy. These difficulties include (1) incomplete pen-

Received Oct. 9, 1998; revised March 2, 1999; accepted March 9, 1999.

Correspondence should be addressed to Dr. Howard Gershenfeld, Department of Psychiatry, University of Texas Southwestern Medical Center, Dallas, TX 75235-8898.

This project has been generously supported by a National Alliance for Research on Schizophrenia and Depression Young Investigators Award (H.G.), the Southwestern Medical Foundation, National Institutes of Health Grant R01-MH58882 (H.G.), and the KZA Hope Fund. P.E.N. is a Canadian Medical Research Council Scholar. We thank C. B. Taylor, I. L. Weissman, and D. Baltimore for encouragement in the larval stages of this project. We appreciated helpful conversations with C. Mathis, J. Crawley, E. Ginns, R. Philibert, E. Remmers, N.Schork, E. Lander, W. Dietrich, W. Berrettini, R. Joho, S. Patel, and W. Frankel, our National Institutes of Health and University of Texas Southwestern Medical Center colleagues. We are grateful to the the Whitehead/Massachusetts Institute of Technology Mouse Genome Project, Research Genetics, K. Manly, and the Mouse Genome Informatics Project for providing the infrastructure for this work.

Copyright (C) 1999 Society for Neuroscience 0270-6474/99/193731-08\$05.00/0 etrance, (2) the presence of phenocopies, (3) genetic heterogeneity (different loci giving rise to a single phenotype), (4) multigenic modes of inheritance, (5) gene interactions, and (6) environmental factors. These complexities render the mapping and positional cloning of loci for complex behaviors challenging in humans. As an alternative, we have chosen to focus on a mouse model of drug-induced epilepsy that offers the advantages of planned matings and controlled environments. Rodent models have already demonstrated utility in mapping genes and quantitative trait loci (QTLs) for epilepsy (Applegate et al., 1989, 1990; Neumann and Seyfried, 1990; Neumann and Collins, 1991; Rise et al., 1991; Frankel et al., 1994, 1995a,b; Frankel, 1995; Noebels, 1996; Buck et al., 1997; Cox et al., 1997; Ferraro et al., 1997; Skradski et al., 1998).

In the present study, we have genetically dissected the variation in seizure response to a $\beta$ carboline convulsant, methyl- $\beta$ carboline-3-carboxylate ( $\beta$-CCM). $\beta$-CCM binds to $\mathrm{GABA}_{\mathrm{A}}$ receptors and exerts an effect opposite to benzodiazepines (i.e., acts as an inverse agonist) to reduce GABA-mediated chloride ion conductance at low concentrations (Im et al., 1995; Barnard et al., 1998). The latter reduces postsynaptic GABAergic inhibitory activity (Tunnicicliff and Raess, 1991; Olsen and Avoli, 1997). $\beta$-CCM is a convulsant when administered to chickens, mice, rats, rabbits, and baboons (Croucher et al., 1984; Prado de Carvalho et al., 1984; Chapman et al., 1985, 1987; Massotti et al., 1985).

In mice, convulsant doses of $\beta$-CCM induce a single brief (10 sec) convulsion of cortical origin with rapid propagation to the hippocampus (Prado de Carvalho et al., 1983). We and others 
have previously demonstrated large differences among inbred mouse strains in their sensitivity to $\beta$ carboline convulsants with a significant heritable component (Kosobud and Crabbe, 1990; Martin et al., 1991, 1992, 1994; Mathis et al., 1995; Chapouthier et al., 1998). We have focused in particular on the sensitive A/J and resistant $\mathrm{C} 57 \mathrm{BL} / 6 \mathrm{~J}$ strains, which differ markedly in their seizure susceptibility to various chemical convulsants (Kosobud and Crabbe, 1990). Recently, segments of chromosomes 4, 9, and 13 have been provisionally mapped as affecting $\beta$-CCM-induced seizures (Martin et al., 1995; Clement et al., 1996). Here, we report the results of a genome-wide search for QTLs influencing susceptibility to $\beta$-CCM in intercross and backcross populations derived from $\mathrm{A} / \mathrm{J}$ and $\mathrm{C} 57 \mathrm{BL} / 6 \mathrm{~J}$ inbred mice.

\section{MATERIALS AND METHODS}

Animals. Male and female A/J (A), C57BL/6J (B6), B6AF1, and F2 hybrid mice 7-8 weeks of age were obtained from Jackson Laboratory (Bar Harbor, ME). B6AF2 mice $(\mathrm{F} 2 ; n=273)$ were derived from an intercross of offspring of a cross between B6 females and A males. N2 mice $(n=220)$ were produced at the University of Texas Southwestern Medical Center (UTSW) from a backcross of B6AF1 females and A males. All mice of the same strain and gender were housed in groups of four to five animals with food and water ad libitum. Animals were maintained under a 12 light/dark cycle with lights on at 6 A.M. F2 mice were identified by ear notching at 7-8 weeks of age followed by $10 \mathrm{~d}$ of adaptation previous to phenotyping. N2 mice were ear-notched at 4 weeks of age and tested at 7-8 weeks of age. Mice were tested individually and weighed on the day of testing. Before testing for response to $\beta$-CCM, mice were subjected to sequential testing in behavioral paradigms: exploratory behavior in an open field (O-F) and light-dark (L-D) transitions, except for the backcross offspring, which were not tested in the L-D transition test. The results of these studies (exploratory behavior in an O-F and L-D transitions of the F2 hybrids) were reported elsewhere (Gershenfeld and Paul, 1997; Gershenfeld et al., 1997). All experiments followed the NIH Guide for the Care and Use of Laboratory Animals.

Seizure testing. Mice were tested for their vulnerability to seizures induced by $\beta$-CCM (Research Biochemicals, Natick, MA) at 10 weeks of age in the $\mathrm{F} 2$ hybrids and at $7-8$ weeks of age in the backcross offspring. $\beta$-CCM was dissolved in $0.1 \mathrm{~N} \mathrm{HCl}(100 \mu \mathrm{l} / \mathrm{mg} \beta$-CCM $)$ and diluted in saline to a final concentration of $1 \mathrm{mg} / \mathrm{ml}$. $\beta$-CCM $(5 \mathrm{mg} / \mathrm{kg})$ was administered intraperitoneally in a volume of $0.1 \mathrm{ml} / 20 \mathrm{gm}$ body weight. The animals received $\beta$-CCM at least $10 \mathrm{~min}$ after being isolated in individual cages. Preliminary dose and time-response studies indicated that $5 \mathrm{mg} / \mathrm{kg}$ was the optimal dose and that $10 \mathrm{~min}$ was the optimal observation period for $\beta$-CCM-induced seizures. Nonseizing animals were assigned a value of $600 \mathrm{sec}$. Thus, mice were observed for the following dependent variables: (1) seizure susceptibility dichotomized as either susceptible (seizure occurred) or resistant (absence of a seizure) and (2) latency of seizures (measured in seconds). Generalized, myoclonic seizures were defined as motor behavior consisting of tonic and clonic alternations, accompanied by a loss of the righting reflex.

$D N A$ preparation and genotyping. DNA was prepared and genotyped as described previously (Gershenfeld and Paul, 1997). Briefly, DNA was genotyped by PCR with MapPair primers (Research Genetics, Huntsville, AL). Initially, a panel of 102 approximately equally spaced CA repeat microsatellite DNA markers were selected (Dietrich et al., 1992, 1996), providing a whole genome screen at a spacing of $\sim 14 \mathrm{~cm}$.

Exploratory behavior in an open field. O-F behavior was performed and analyzed as described previously (Gershenfeld et al., 1997), except that the backcross offspring were tested at UTSW for O-F in a newer apparatus (Opto-Varimex-3, Columbus Instruments, Columbus, OH; 730 lux at cage floor). The dimensions of the square field were $43 \times 43 \times 30.5$ $\mathrm{cm}$, and the vertical sensor was positioned $8 \mathrm{~cm}$ above the cage floor. Briefly, O-F behavior consisted of three consecutive 5 min epochs (e1, e2, e3) (15 min total), and the following dependent measures were assessed: (1) initial total distance (TDe1), the distance travelled or ambulated during the initial $5 \mathrm{~min}$ epoch, epoch 1 ; (2) habituated total distance (TDe3), the distance travelled or ambulated during the last 5 min epoch, epoch 3; and (3) vertical movements (VM15), the sum of vertical movements (rearings) during the first trial of $15 \mathrm{~min}$.
Statistical analysis. The presence or absence of seizures was treated as a dichotomous, nominal variable. Latency to seizure was measured as a continuous variable. The genetic component of the variance in the F2 generation and its error (i.e., the broad sense heritability) were estimated as described (Falconer, 1963). Analysis of components of the means was performed as described previously (Neumann et al., 1993). Because no suitable transformation of the latency-to-seizure trait variable could be found (to obtain a normal distribution and equalize the variances among groups), the data were subsequently analyzed nonparametrically. By rank ordering the latency-to-seizure variable, the "ceiling effect" of arbitrarily assigning nonseizing mice a value of $600 \mathrm{sec}$ was mitigated.

Overall differences in latency to seizure and percentage of animals with a myoclonic seizure were compared across gender, strain, and generation by nonparametric tests for significant differences with MannWhitney $U$, Kruskal-Wallis, and $\chi^{2}$ tests (Statview 4.5 and SuperAnova, Abacus Concepts and JMP 3.02, SAS Institute).

For linkage detection, we initially used $\chi^{2}$ tests of independence between markers and seizure susceptibility (i.e., the presence or absence of seizure), which are inherently model-free. For single-point linkage of seizure latency and a marker, the seizure latency values were rankordered and analyzed by the Kruskal-Wallis test for the F2 population and the Mann-Whitney $U$ tests for the backcross (N2) population (Sokal and Rohlf, 1995). The Mapmaker/QTL (Lander et al., 1987; Paterson et al., 1991; Lincoln and Lander, 1992) and Map Manager QTLb21 (Manly, 1998) programs were used to confirm, localize, and estimate the percentage of the phenotypic variance explained for each QTL. For interpreting the seizure linkage results, we used the empirically derived statistical threshold criteria generated from permutation tests on the data (shuffling randomly the genotypes and phenotypes 10,000 times) (Churchill and Doerge, 1994; Manly, 1998). These empirically derived threshold definitions for suggestive and significant linkage correspond to the established $p$ values based on the number of times that one would be expected to find such a result at random under the more stringent assumption of a dense marker map genome scan (Lander and Kruglyak, 1995). Suggestive linkage thresholds define a level at which just one occurrence at random in a genome scan would be expected, whereas the significant linkage threshold would be surpassed statistically 0.05 times in a genome scan. For the F2 population, the permutations of the ranked seizure latency determined the thresholds for suggestive and significant linkage as logarithm of the likelihood for linkage (LOD) scores of 2.3 and 3.7, respectively. For the N2 population, the threshold values for suggestive and significant linkage were LOD scores of 1.4 and 2.7, respectively. Finally, the data were modeled by stepwise linear and nominal logistic regression to find the best fitting model and to obtain odds ratios (Kleinbaum, 1994; Sokal and Rohlf, 1995). For interpreting the exploratory behavioral traits' linkage results, we used the published guidelines (Lander and Kruglyak, 1995). The percentage of the genetic component of the variance explained by a QTL was estimated by dividing the percentage of the phenotypic variance explained by the estimated heritability. Epistatic interactions were examined by linear regression analysis, testing for statistical interactions among mapped loci as described (Cheverud and Routman, 1995).

\section{RESULTS}

\section{Segregation analysis}

$\mathrm{A} / \mathrm{J}$ mice were more susceptible to $\beta$-CCM-induced myoclonic seizures than B6 mice in both latency to seizure and proportion of tested mice that seized $(p<0.0001)$ (Table 1$)$. The parental strains differed in effect size by $1 \mathrm{SD}$ in their latency to $\beta$-CCMinduced seizures. Preliminary experiments with the parental strains at 7 and 10 weeks (data not shown) showed no difference in seizure frequency or latency to seizure between age groups.

Seizure resistance showed partial dominance. The F1 hybrids were less susceptible than the theoretical midparental $(m)$ values for both seizure frequency and latency but were more susceptible than B6 mice without reaching statistical significance. The broad sense heritability of seizure latency was estimated in the F2 hybrids to be $0.28 \pm 0.10$; however, this estimate makes the false 
A

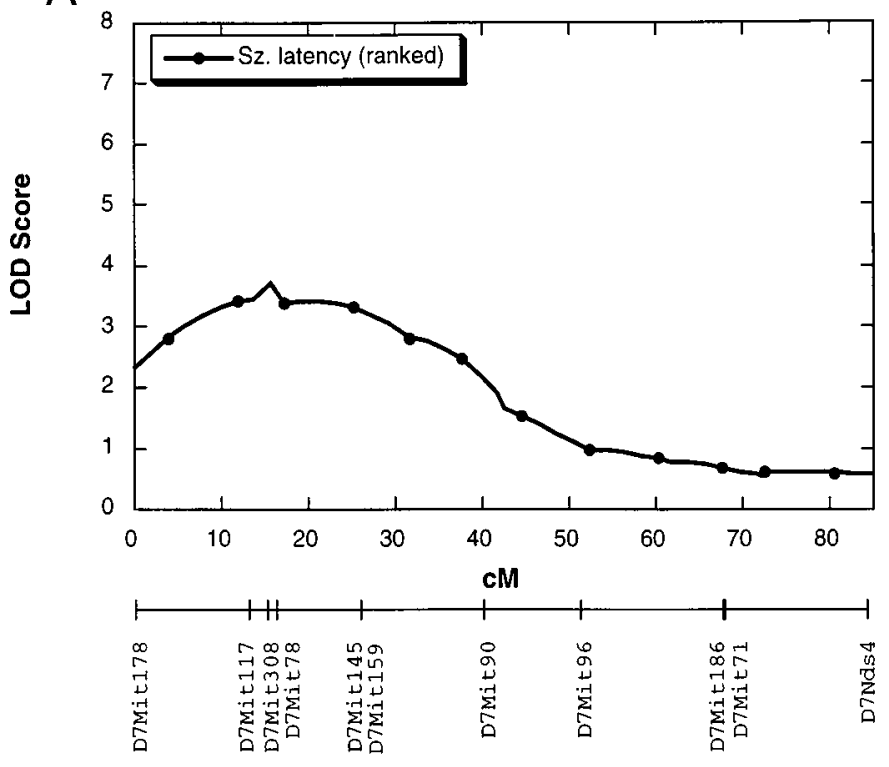

B

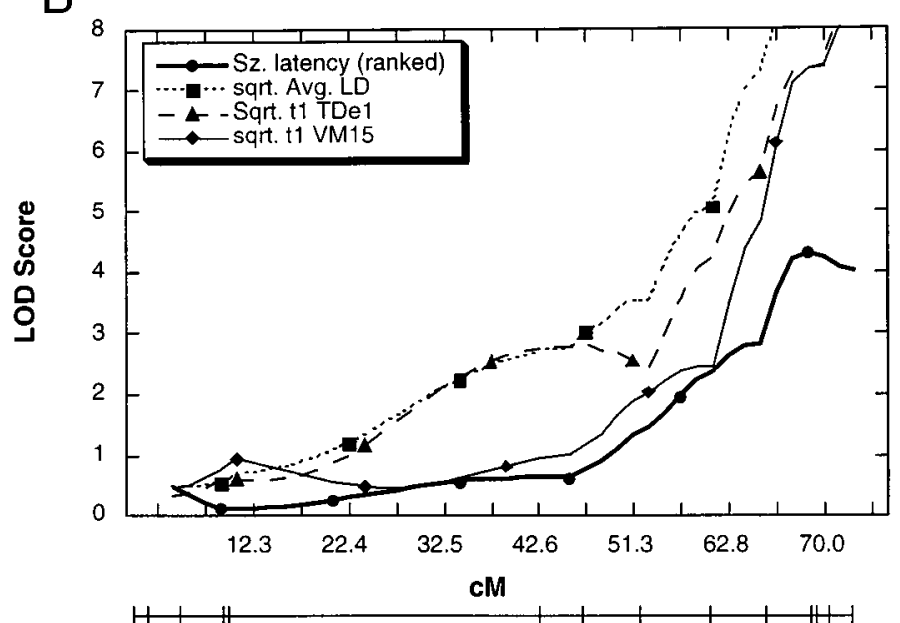

Chromosome 10

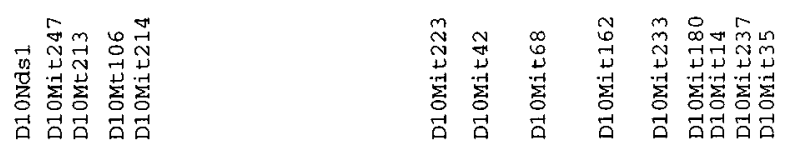

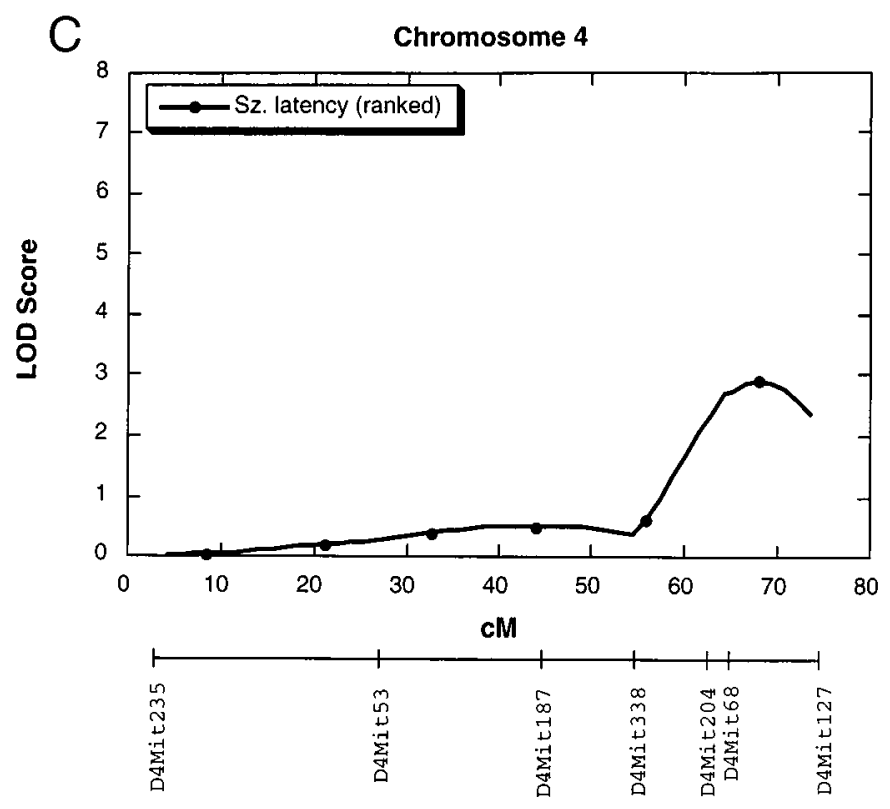

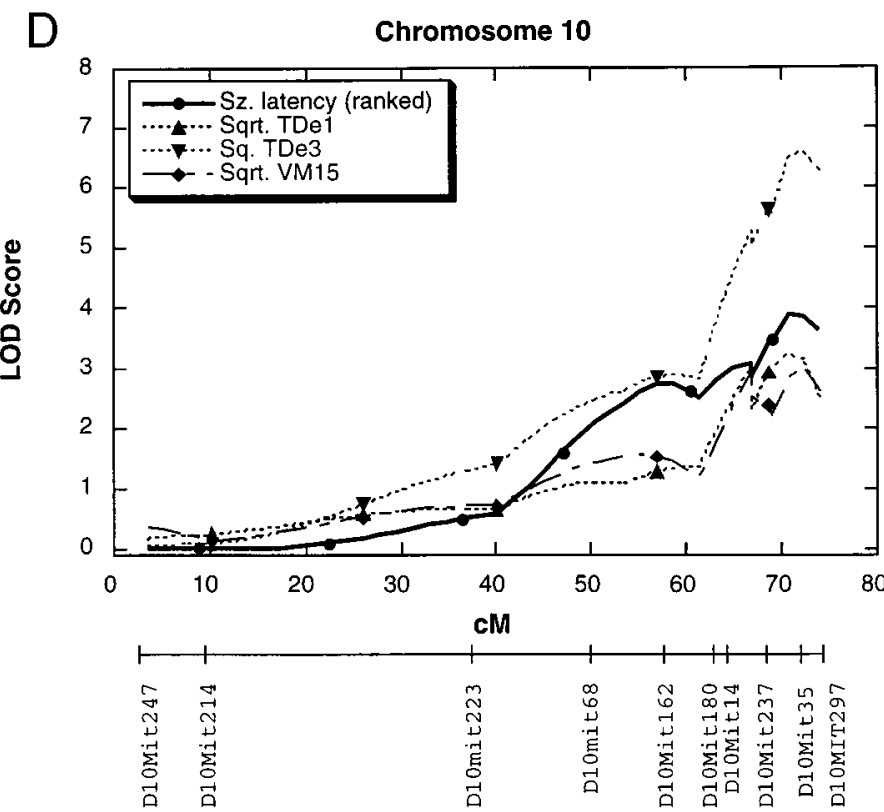

Figure 1. QTL likelihood plots on the $\mathrm{F} 2$ population for $(A)$ chromosome 7 and $(B)$ chromosome 10 and on the N2(B6AF1xA/J) backcross population for $(C)$ chromosome 4 and $(D)$ chromosome 10 from Mapmaker/QTL analyses. Logarithm of the likelihood ratio for linkage (LOD) score is plotted against map distance in centimeters for the traits of seizure latency, rank-ordered $(\bullet)$, average of three trials of light $\leftrightarrow$ dark transitions (AvgLD, $\mathbf{\square})$, initial O-F total distance ambulated (TDe1, $\mathbf{\Delta}$ ), habituated O-F total distance ambulated (TDe3, [tridf]), and O-F vertical movements (VM15, $\bullet$ ). For the F2 hybrids with $2 \mathrm{df}$, the published threshold values for suggestive and significant linkage are LOD $=2.8$ and LOD $=4.3$, respectively, whereas the empirically derived threshold values from 10,000 permutations for the ranked latency to seizure gave values of 2.3 and 3.7 , respectively. For the $\mathrm{N} 2(\mathrm{~B} 6 \mathrm{AF} 1 \mathrm{xA} / \mathrm{J})$ cross with $1 \mathrm{df}$, the published threshold values for suggestive and significant linkage are LOD $=1.9$ and LOD $=3.3$, respectively, whereas the empirically derived values for the ranked latency to seizure gave values of 1.4 and 2.7. These QTL plots used the genotyping of 11 and 12 DNA markers for chromosome 7 and 10 in the F2 hybrids, whereas the backcross offspring used the genotyping of 7 and 10 DNA markers for chromosomes 4 and 10, respectively.

assumption of a normal distribution of the data. Analysis of the components of the means was consistent with a simple model of the mode of inheritance requiring no interaction parameters. The parameters $m(0.45), a(0.23)$, and $d(-0.12)$ were calculated from the seizure frequencies in the B6, A, and F1 populations. The predicted seizure frequencies in the $\mathrm{F} 2(m+d / 2=0.39)$ and N2 $(m+a / 2+d / 2=0.51)$ were not significantly different from the observed values (36 and 51\%). 
Table 1. Seizure frequency and latency in parental, F1, F2 hybrid, and backcross mice injected with $\beta$-CCM

\begin{tabular}{|c|c|c|c|c|}
\hline \multirow[b]{2}{*}{ Generation } & \multirow[b]{2}{*}{$n$} & \multirow[b]{2}{*}{$\%$ Seizure } & \multicolumn{2}{|c|}{ Latency to seizure } \\
\hline & & & Mean & $\mathrm{SD}(\mathrm{sec})$ \\
\hline C57BL6/J & 49 & 22 & 510 & 171.94 \\
\hline $\mathrm{A} / \mathrm{J}$ & 66 & $68^{a}$ & $248^{b}$ & 251.96 \\
\hline$(\mathrm{B} 6 \mathrm{xA}) \mathrm{F} 1$ & 40 & 33 & 494 & 195.67 \\
\hline $\mathrm{F} 2$ & 273 & 36 & 419 & 246.11 \\
\hline$(\mathrm{B} 6 \mathrm{AF} 1 \mathrm{xA}) \mathrm{N} 2$ & 220 & 51 & 337 & 260.86 \\
\hline
\end{tabular}

Maximum seizure latency was $600 \mathrm{sec}$.

${ }^{a} \mathrm{~A} / \mathrm{J}$ significantly different from B6 and F1 by Fisher's Exact test, $p<0.0006$.

${ }^{b}$ Mann-Whitney $U$ test, $p<0.0001$.

\section{Linkage analysis of seizure susceptibility in intercross offspring}

From the phenotypic rankings of the latency-to-seizure trait, F2 animals within the lowest and highest (17\% tails) of the distribution ("phenotypic extremes") were selected for initial genotyping. We mapped loci using a three-stage strategy. In stage I, $\chi^{2}$ tests of independence between markers and seizure susceptibility were calculated from a genome-wide screen on the phenotypic extremes. Six peak marker loci (D1Mit353, D7Mit78, D8Mit69, D10Mit14, D15Mit11, and D18Mit4) were identified with $\chi^{2}$ tests surpassing a relatively low threshold of statistical significance $(p=0.05)$, which was selected to limit type II errors (Elston, 1994). In the second stage, flanking DNA markers surrounding the six stage I candidate loci were selected and genotyped on the extremes. Then, we merged this genotype data on the seizure phenotypic extremes with our previous genotype data on the behavioral traits' phenotypic extremes, creating a pooled dataset. With this enlarged dataset, the Mapmaker/QTL computer program was used to localize and model these potential QTLs. Only two loci located on chromosomes 7 and 10 met the "suggestive" level of significance criteria for LOD cutoff thresholds for link- age. In stage III, we "genotyped" the entire F2 population with markers in the regions of interest. This step reduced errors attributable to assumptions implicit in modeling the whole distribution from non-normally distributed populations with missing data. Finally, the F2 data were reanalyzed with the single point nonparametric statistics (Sokal and Rohlf, 1995), Mapmaker/ QTL, and logistic regression.

D7Mit308 on proximal chromosome 7 displayed association with seizure susceptibility $\left(\chi^{2}=14.8, p=0.006,2 \mathrm{df} ; n=267\right)$ and seizure latency (Table 2, Fig. $1 A$ ).

D10Mit180 on distal chromosome 10 was associated with seizure susceptibility $\left(\chi^{2}=15.77, p=0.004,2 \mathrm{df} ; n=271\right)$ and seizure latency (Table 2, Fig. $1 B$ ). The B allele for the potential QTL near D10Mit180 displayed near complete dominance.

The best-fitting logistic regression model suggests that the A allele at the D7Mit308 locus increases the likelihood of seizures $\sim 3.3$-fold, and the A allele at the D10Mit180-linked locus increases the likelihood of seizure by $\sim 2.7$-fold (Table 3 ). The contribution of these QTLs to the phenotypic variance was estimated similarly from stepwise linear regression and Mapmaker/ QTL (Table 2), where each locus individually accounted for $5-7 \%$ of the phenotypic variation. Together the two loci explain $11-12 \%$ of the phenotypic variation and roughly $40 \%$ of the genetic variation in the F2 generation. No epistatic interactions were detected between these loci. No additional QTLs were mapped in models that fix the identified QTL or in models that included only susceptible mice $(n=98)$.

\section{Linkage analysis of seizure susceptibility in backcross offspring}

The chromosome 10 QTL was robustly confirmed in the backcross offspring. D10Mit237, which is located $\sim 4 \mathrm{~cm}$ distal to D10Mit180, displayed significant association with seizure susceptibility ( $\left.\chi^{2}=19.30,1 \mathrm{df}, p<0.0001 ; n=214\right)$ and seizure latency (Table 2, Fig. 1D).

A genome-wide scan with 102 markers in the backcross mapped only one other QTL at the suggestive level of statistical signifi-

\begin{tabular}{|c|c|c|c|c|c|c|c|c|c|c|c|}
\hline \multirow[b]{2}{*}{ Cross and trait } & \multicolumn{5}{|l|}{ Mapmaker QTL } & \multicolumn{6}{|c|}{ Mean comparisons by genotype } \\
\hline & Marker $+\mathrm{cM}$ & $\begin{array}{l}\text { Pos. in } \\
\mathrm{cM}\end{array}$ & $\begin{array}{l}\text { LOD } \\
\text { score }\end{array}$ & $\begin{array}{c}\% \\
\text { Var }\end{array}$ & Weight & df & $\begin{array}{c}H, U, \\
\text { or } F \\
\text { test }\end{array}$ & $p$ value & $\begin{array}{c}\text { Mean of } \\
\text { B/B } \\
(\% \mathrm{Sz})\end{array}$ & $\begin{array}{c}\text { Mean of } \\
\text { B/A } \\
(\% \mathrm{Sz})\end{array}$ & $\begin{array}{l}\text { Mean of } \\
\text { A/A } \\
(\% \mathrm{Sz})\end{array}$ \\
\hline \multicolumn{12}{|l|}{$\mathrm{F} 2$ intercross } \\
\hline$\beta$-CCM seizure & D7Mit308 +0 & 13.7 & 3.71 & 6.1 & 22.03 & 2 & 17.3 & 0.0002 & $161.4(18.3)$ & $127.5(41.4)$ & $116.9(47.6)$ \\
\hline Latency, ranked & D10Mit180 + 0 & 67.8 & 4.29 & 7.0 & 7.0 & 2 & 18.9 & $<0.0001$ & $152.8(25.5)$ & $146.1(29.5)$ & $110.4(52.9)$ \\
\hline \multicolumn{12}{|l|}{$\mathrm{N} 2$ backcross } \\
\hline$\beta$-CCM seizure & D4Mit68 +4 & 70.7 & 2.88 & 6.8 & 31.63 & 1 & 4281 & 0.0005 & & $123.3(41.1)$ & $93.8(62.9)$ \\
\hline Latency, ranked & D10Mit237 + 4 & 76.1 & 4.36 & 8.8 & 154.85 & 1 & 4398 & 0.0003 & & $413.8(38.9)$ & $257.3(65.4)$ \\
\hline \multicolumn{12}{|l|}{ O-F exploration } \\
\hline $\begin{array}{l}\text { Sqrt. Tot. Dist. } \\
\text { initial (TDel) }\end{array}$ & D10Mit237 + 2 & 74.1 & 3.19 & 6.8 & 4.71 & 1,208 & 12.69 & 0.0005 & & 40.8 & 36.5 \\
\hline $\begin{array}{l}\text { Sqrt. Tot. Dist. } \\
\text { habituated (TDe3) }\end{array}$ & D10Mit237 + 4 & 76.1 & 6.53 & 12.8 & 6.87 & 1,212 & 27.84 & $<0.0001$ & & 34.9 & 28.4 \\
\hline Sqrt. VM15 & D10Mit237 + 4 & 76.1 & 2.98 & 6.2 & 1.27 & 1,208 & 18.33 & $<0.0001$ & & 8.5 & 7.2 \\
\hline
\end{tabular}

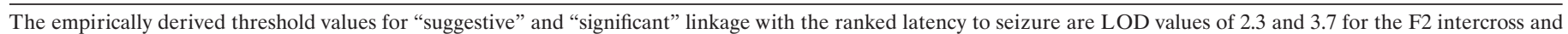

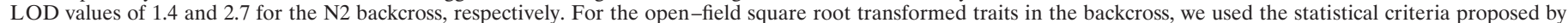

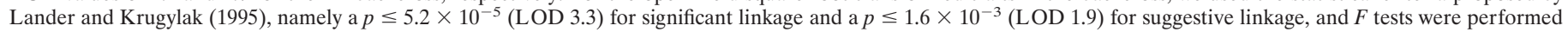

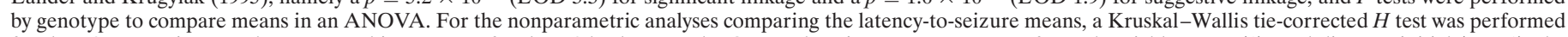

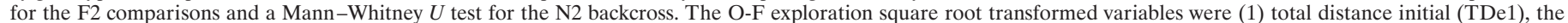

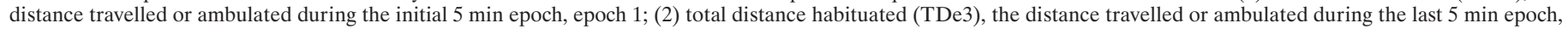
epoch 3; and (3) vertical movements (VM15), the sum of vertical movements (rearings) during the first trial of 15 min. 
cance. D4Mit68 on distal chromosome 4 was associated with seizure susceptibility $\left(\chi^{2}=10.3,1 \mathrm{df}, p=0.0013 ; n=217\right)$ and seizure latency (Table 2, Fig. $1 C$ ).

The best fitting logistic regression model suggests that the $\mathrm{B}$ allele at the D4Mit68-linked locus increased the likelihood of resistance by 2.3-fold, and the B allele at the D10Mit237-linked locus increased it by 2.8-fold (Table 4). Each locus accounted for $6-9 \%$ of the phenotypic variance (Table 2). Together these two loci explained $\sim 11.8 \%$ of the phenotypic variance. The chromosome 7 locus mapping in the F2 hybrids and the previously mapped loci (Martin et al., 1995; Clement et al., 1996) on chromosomes 9 and 13 could not be confirmed. No statistical epistatic interactions were detected, and no additional QTLs were mapped in models that fix the identified QTL.

\section{Linkage analysis of behavioral phenotypes in backcross offspring}

$\mathrm{O}-\mathrm{F}$ behaviors in the backcross offspring were tested for association with marker loci on distal chromosome 10 because the co-localization of a seizure susceptibility QTL with a previously reported QTL for O-F exploratory (Gershenfeld et al., 1997) and fear-like (Gershenfeld and Paul, 1998) behaviors in B6AF2 hybrid mice suggested the possibility of a single pleiotropic QTL (Fig. 1B). D10Mit237 displayed significant association with O-F initial (TDe1) and habituated (TDe3) ambulation and O-F vertical movement (VM15) in the backcross population (Table 2, Fig. 1D). Consequently, we named this distal chromosome 10 locus Exq1 (exploratory and excitability QTL) because it appears to affect both O-F exploratory behavior (TDe1, TDe3, VM15) and $\beta$-CCM-induced seizure susceptibility. Exq1 explains $6-13 \%$ of the phenotypic variance and from $13-31 \%$ of the genetic variance for the various O-F exploratory traits listed in the backcross population (Table 2). Consistent with the observations in the F2 population (Gershenfeld et al., 1997), the B6 allele of Exq1 is an increasing allele for all the O-F traits in the backcross populations (Table 2).

\section{DISCUSSION}

By using the $\mathrm{GABA}_{\mathrm{A}}$ receptor inverse agonist $\beta$-CCM as a pharmacological probe, we examined the genetic basis of individual differences in seizure behavior in offspring derived from the A and B6 mice. In general, the A strain is a seizure-susceptible strain, and B6 mice are a seizure-resistant strain based on their susceptibility to nine chemoconvulsants (Kosobud and Crabbe, 1990). We selected this particular drug-induced paradigm as a model of individual differences in susceptibility to seizures, because previous work had shown robust strain differences (Martin et al., 1991, 1993, 1994; Mathis et al., 1994, 1995) that reflect presumed genetic differences in seizure threshold and "GABA inhibitory tone"(Tunnicicliff and Raess, 1991; Olsen and Avoli, 1997). The drug has been demonstrated to rapidly induce a single brief convulsion within $10 \mathrm{~min}$, and the drug has behavioral activity for at least $30 \mathrm{~min}$ after its injection (Prado de Carvalho et al., 1984). By measuring the latency to seizure after a $5 \mathrm{mg} / \mathrm{kg}$ i.p. injection with $\beta$-CCM, we confirmed significant betweenstrain differences and estimated a heritability of $0.28 \pm 0.10$ in this F2 population, similar to our previous findings from RI strains (Mathis et al., 1995). Genome wide screens mapped QTLs for seizure susceptibility on proximal chromosome 7 and distal chromosome 10 in intercross offspring, and on distal chromosome 4 and distal chromosome 10 QTL in backcross offspring. Only the QTL on chromosome 10 was detected in both the intercross and the backcross, probably because of dominance relationships. The confidence interval of the suggestive QTL on distal chromosome 4 overlaps with that of a $\beta$-CCM susceptibility QTL, Bis 1 (Martin et al., 1995). In the crosses reported here, we could not confirm the provisionally mapped QTLs on chromosomes 9 or proximal 13 , inferred as influencing $\beta$-CCM-induced seizures (Martin et al., 1995; Clement et al., 1996).

We have named the chromosome 7 QTL Bis 4 ( $\beta$-carbolineinduced seizure 4). This QTL confirmed our previous suggestive locus (near Pmv15) from a recombinant inbred strain linkage analysis (Mathis et al., 1995), whereas the other potential QTLs may be small effect loci or spurious loci secondary to limited statistical power (Neumann, 1992; Belknap et al., 1996). The broad, flat Bis4 likelihood plot (Fig. $1 A$ ) has a large 1 LOD support interval ranging from 2 to 30 centimorgans (cM) and corresponds to human regions $19 \mathrm{q} 13,11 \mathrm{p} 15$, and 15q11-q13. This interval contains several appealing candidate genes: Atpla3 (Na,K-ATPase 1a3), Atp1b3 (Na,K-ATPase 1b3), Grik5 (glutamate receptor, kainate 5, $\gamma 2$ ), and $S c n 1 b$ (voltage-gated sodium channel, type I, $\beta$ polypeptide). We cannot exclude as candidate genes the cluster of three $\mathrm{GABA}_{\mathrm{A}}$ receptor subunits $(\alpha 5, \beta 3$, gamma3) or the seizure susceptibility QTLSzf1 (Frankel et al., 1994) at roughly $28 \mathrm{cM}$. Human association studies for juvenile myoclonic epilepsy in this region have been equivocal (Sander et al., 1997), but mice deficient in the $\beta 3$ subunit have an increased susceptibility to seizures (Homanics et al., 1997). The Bis4 QTL interval is probably proximal to the Asp3 locus, which influenced audiogenic seizures (Neumann and Collins, 1991; Banko et al., 1997). In addition, we believe that Bis4 is probably distinct from Asp3, because previous work has shown no correlation between $\beta$-CCM-induced seizures and audiogenic seizures among 33 B10.D2 recombinant congenic strains (Martin et al., 1992).

We named the distal chromosome 10 locus Exq1 because it appears to affect O-F exploratory behavior (TDe1, TDe3, VM15), L-D behavior, and $\beta$-CCM-induced seizure behavior. Although the most parsimonious explanation for the pleiotropic effects of distal chromosome 10 is a single locus, much higher resolution fine mapping will be needed to exclude the possibility of two closely linked loci. The steep QTL likelihood plots (Fig. 1) for Exq1 on the habituated total distance (TDe3) in the backcross suggest a more discrete localization of the locus to the telomericmost $15 \mathrm{cM}$, corresponding to human chromosomes 12q11-14 and $12 q 24$. If one interprets our strain differences as individual differences in major behavioral systems [where open field behavior reflects a behavioral inhibition system (Kagan et al., 1988; Gray and NcNaughton, 1996; Gershenfeld et al., 1997), where $\beta$-CCMinduced seizures interrogates the "set point" of GABA neuronal inhibition (Nutt et al., 1992), and where the L-D paradigm reflects a "fear-like" system (Gershenfeld and Paul, 1997)], then a mechanistic understanding of the Exq1 gene product should be informative in understanding the interrelationship among these higher order behaviors. We speculate that this locus functions as a neuronal modulator (distinct from the known neurotransmitter and receptor complexes) because no known candidate genes map to this region. Although conceivable neuromodulators abound, the list might include factors known to affect $\mathrm{GABA}_{\mathrm{A}}$ receptor function such as growth factors (Wan et al., 1997), protein kinases (Lin et al., 1996; McDonald and Moss, 1997), neurosteroids (Paul and Purdy, 1992; Purdy et al., 1992; Lambert et al., 1996; Rupprecht et al., 1996), endogenous benzodiazapine ligands (Polc, 1995; Wichlinski, 1996), and transcriptional factors (Berninger et al., 1995; Sadar et al., 1996; Ashiya and Grabowski, 1997) differ- 


Table 3. Logistic regression model estimates of intercross offspring
Marker

${ }^{a}$ Regression analysis was conducted by defining susceptibility to seizures as the nominal dependent variable, and marker data were recoded to determine the best fitting mode of inheritance; results are given for the strain contributing the susceptibility allele. Dom, Dominance; Rec, recessive. The coefficient with SE is a parameter for the slope term reflecting the strength of the relationship between cumulative probability for a seizure as a function of the range of genotypes at the given loci for this model.

Table 4. Logistic regression model estimates of backcross offspring
Marker
\begin{tabular}{lllccc} 
& & & \\
Allele/mode & Coefficient + SE & Wald $\chi^{2}$ & $p$ value & Odds ratio \\
\hline D7Mit308 & B6/Dom & $0.84 \pm 0.29$ & 8.53 & 0.0035 & 2.32 \\
D10Mit180 & B6/Rec & $1.05 \pm 0.29$ & 13.16 & 0.0003 & 2.85
\end{tabular}

$\overline{{ }^{a} \text { Regression analysis was conducted by defining resistance to seizures as the nominal dependent variable, and marker data }}$ were recoded to determine the best fitting mode of inheritance; results are given for the strain contributing the resistance allele. Dom, Dominance; Rec, recessive. The coefficient with SE is a parameter for the slope term reflecting the strength of the relationship between cumulative probability for the absence of a seizure as a function of the range of genotypes at the given loci for this model.

entially regulated between the two strains. The ultimate positional cloning of this locus may clarify the etiological mechanism. From a therapeutic perspective, one might speculatively consider the role of a dominantly acting locus as a "protective" allele, especially in "all or none" threshold behaviors such as seizures. It is possible that the effect of relatively modest genes on an underlying threshold may be clinically significant. As developments in brain stem cells and vectors progress (Lawrence et al., 1995; O'Connor et al., 1997; Xiao et al., 1997; Zhang et al., 1997), one can imagine gene therapy for people with medication refractive epilepsy, where one might overexpress a mixture of such protective loci as Exq1 in the susceptible individual's tissue to increase the seizure threshold or lessen the spread of paroxysmal neuronal discharges.

The distal chromosome 4 QTL interval mapped in the backcross confirms the previously mapped Bis 1 QTL near je (Martin, Clement et al., 1995). Two serotonin receptor gene subunits that map to this region (Htrlda and Htrldb) have some plausibility as regulators of seizure threshold. A third candidate gene is the Slc9al (formerly known as NheI), which encodes a $\mathrm{Na}^{+} / \mathrm{H}^{+}$ exchange protein. The etiology of the slow-wave epilepsy mutant mouse was recently attributed to a $S l c 9 a 1$ null mutation (Cox et al., 1997). The region of conserved synteny in humans corresponds to $1 \mathrm{p} 36-32$.

Several limitations should be considered in interpreting our findings. The sample populations represent crosses between just two strains of mice and may not be generalizable to other strains. The sample sizes of the F2 and backcross offspring populations were relatively small, and hence QTLs with an effect of $<5 \%$ of the phenotypic variance would not reach statistical significance. In general, the complexity of interpreting drug response patterns in populations derives from the multiple genetic factors affecting pharmacokinetics as well as pharmacodynamics. We cannot formally rule out pharmacokinetic explanations because we did not measure brain $\beta$-CCM levels. In this regard, strain differences in $\beta$-CCM-induced seizures between the NIH:GP (an outbred population of Swiss mice) and a derived line NIH:N population were attributed to a pharmacokinetic difference at 4-6 weeks of age, whereas no such strain difference in susceptibility was detected at 8-10 weeks of age (Schweri et al., 1983b). Although the plasma $t_{1 / 2}$ of $\beta$-CCM in rats is short ( $\sim 3 \mathrm{~min}$ ) (Schweri et al., 1983a), experiments in mice have demonstrated active drug effects in behavioral paradigms for at least $30 \mathrm{~min}$ after injection at subconvulsant doses (Prado de Carvalho et al., 1984). However, it seems unlikely that pharmacokinetic differences could explain our results because (1) we phenotyped animals at 8-10 weeks of age, (2) the A and B6 lines differ for many chemoconvulsants (Kosobud and Crabbe, 1990), and (3) seizures usually occur within the first $6 \mathrm{~min}$.

The Bis4 and Exq1 QTLs reported here are likely to be distinct from previously mapped loci for various mouse seizure phenotypes (Neumann and Seyfried, 1990; Neumann and Collins, 1991, 1992; Rise et al., 1991; Frankel et al., 1994, 1995a,b; Miner and Marley, 1995; Clement et al., 1996; Buck et al., 1997; Ferraro et al., 1997; Skradski et al., 1998), and our distal chromosome 4 QTL supports the chromosomal assignment of Bis1 (Martin et al., 1995). Previous work on genetic correlations among inbred strains with chemoconvulsants (Kosobud and Crabbe, 1990) and the $>80$ discrete knockout transgenic strains presenting with seizures as a phenotype (Noebels, 1996) suggest a multiplicity of genes affecting seizure susceptibility. The current mapping of distinct loci specific for vulnerability to a $\mathrm{GABA}_{\mathrm{A}}$ receptor inverse agonist model of seizures underscores the emerging construct of multigenic, genetically heterogenous models of epilepsy, where each mouse model may uniquely represent an underlying seizure mechanism (Anderson et al., 1986; Frankel et al., 1994; McNamara, 1992, 1994). We anticipate that the positional cloning and functional analysis of the loci influencing $\beta$-CCM-induced seizures will substantially contribute to our understanding of the basic cellular mechanisms affecting seizure vulnerability. Moreover, the positional cloning of the Exq1 locus with its presumed pleiotropic effects on seizure threshold, open-field, and fear-like behaviors may provide insights into the pathophysiology of individual differences in CNS excitability.

\section{REFERENCES}

Anderson VE, Hauser WA, Rich SS (1986) Genetic heterogeneity in the epilepsies. Adv Neurol 44:59-75.

Applegate CD, Samoriski G, Neumann PE (1989) Susceptibility to electroconvulsive shock in DBA/2J and C57BL/6J mice: a classic genetic and recombinant inbred strain analysis. Epilepsia 30:699. 
Applegate CD, Burchfiel JL, Neumann PE (1990) Genetic contributions to kindling: an experimental approach. In: Kindling 4 (Wada JA, ed), pp 113-125. New York: Plenum.

Ashiya M, Grabowski PJ (1997) A neuron-specific splicing switch mediated by an array of pre-mRNA repressor sites: evidence of a regulatory role for the polypyrimidine tract binding protein and a brain-specific PTB counterpart. RNA 3:996-1015.

Banko ML, Allen KM, Dolina S, Neumann PE, Seyfried TN (1997) Genomic imprinting and audiogenic seizures in mice. Behav Genet 27:465-475.

Barnard EA, Skolnick P, Olsen RW, Mohler H, Sieghart W, Biggio G, Braestrup C, Bateson AN, Langer SZ (1998) International Union of Pharmacology. XV. Subtypes of gamma-aminobutyric acidA receptors: classification on the basis of subunit structure and receptor function. Pharmacol Rev 50:291-313.

Belknap JK, Mitchell SR, O’Toole LA, Helms ML, Crabbe JC (1996) Type I and type II error rates for quantitative trait loci (QTL) mapping studies using recombinant inbred mouse strains. Behav Genet 26:149-160.

Berkovic SF, Howell RA, Hay DA, Hopper JL (1998) Epilepsies in twins: genetics of the major epilepsy syndromes. Ann Neurol 43:435-445.

Berninger B, Marty S, Zafra F, da Penha Berzaghi M, Thoenen H, Lindholm D (1995) GABAergic stimulation switches from enhancing to repressing BDNF expression in rat hippocampal neurons during maturation in vitro. Development 121:2327-2335.

Buck KJ, Metten P, Belknap JK, Crabbe JC (1997) Quantitative trait loci involved in genetic predisposition to acute alcohol withdrawal in mice. J Neurosci 17:3946-3955.

Chapman AG, Cheetham SC, Hart GP, Meldrum BS, Westerberg E (1985) Effects of two convulsant beta-carboline derivatives, DMCM and beta-CCM, on regional neurotransmitter amino acid levels and on in vitro D-[3H]aspartate release in rodents. J Neurochem 45:370-381.

Chapman AG, De Sarro GB, Premachandra M, Meldrum BS (1987) Bidirectional effects of beta-carbolines in reflex epilepsy. Brain Res Bull 19:337-346.

Chapouthier G, Launay JM, Venault P, Breton C, Roubertoux PL, Crusio WE (1998) Genetic selection of mouse lines differing in sensitivity to a benzodiazepine receptor inverse agonist. Brain Res 787:85-90.

Cheverud JM, Routman EJ (1995) Epistasis and its contribution to genetic variance components. Genetics 139:1455-1461.

Churchill GA, Doerge RW (1994) Empirical threshold values for quantitative trait mapping. Genetics 138:963-971.

Clement Y, Martin B, Venault P, Chapouthier G (1996) Mouse chromosome 9 involvement in beta-CCM-induced seizures. NeuroReport 7:2226-2230.

Colenda CC, McCall WV (1996) A statistical model predicting the seizure threshold for right unilateral ECT in 106 patients. Convuls Ther 12:3-12.

Cox GA, Lutz CM, Yang CL, Biemesderfer D, Bronson RT, Fu A, Aronson PS, Noebels JL, Frankel WN (1997) Sodium/hydrogen exchanger gene defect in slow-wave epilepsy mutant mice. Cell 91:139-148.

Croucher M, De Sarro G, Jensen L, Meldrum B (1984) Behavioural and convulsant actions of two methyl esters of beta-carboline-3-carboxylic acid in photosensitive baboons and in DBA/2 mice. Eur J Pharmacol 104:55-60.

Dietrich WF, Katz H, Lincoln SE, Shin HS, Friedman J, Dracopoli NC, Lander ES (1992) A genetic map of the mouse suitable for typing intraspecific crosses. Genetics 131:423-447.

Dietrich WF, Miller J, Steen R, Merchant MA, Damron-Boles D, Husain Z, Dredge R, Daly MJ, Ingalls KA, O'Connor TJ (1996) A comprehensive genetic map of the mouse genome. Nature 380:149-152.

Elmslie FV, Williamson MP, Rees M, Kerr M, Kjeldsen MJ, Pang KA, Sundqvist A, Friis ML, Richens A, Chadwick D, Whitehouse WP, Gardiner RM (1996) Linkage analysis of juvenile myoclonic epilepsy and microsatellite loci spanning $61 \mathrm{cM}$ of human chromosome $6 \mathrm{p}$ in 19 nuclear pedigrees provides no evidence for a susceptibility locus in this region. Am J Hum Genet 59:653-663.

Elston RC (1994) P values, power and pitfalls in the linkage analysis of psychiatric disorders. In: Genetic approaches to mental disorders (Gershon ES, Cloninger CR, eds), pp 3-21. Washington, DC: American Psychiatric Press.

Falconer DS (1963) Quantitative inheritance. In: Methodology in mam- malian genetics (Burdette WJ, ed), pp 193-216. San Francisco: Holden-Day.

Ferraro TN, Golden GT, Smith GG, Schork NJ, Jean PS, Ballas C, Choi H, Berrettini WH (1997) Mapping murine loci for seizure response to kainic acid. Mamm Genome 8:200-208.

Frankel WN (1995) Taking stock of complex trait genetics in mice. Trends Genet 11:471-477.

Frankel WN, Taylor BA, Noebels JL, Lutz CM (1994) Genetic epilepsy model derived from common inbred mouse strains. Genetics 138:481-489.

Frankel WN, Johnson EW, Lutz CM (1995a) Congenic strains reveal effects of the epilepsy quantitative trait locus, El2, separate from other El loci. Mamm Genome 6:839-843.

Frankel WN, Valenzuela A, Lutz CM, Johnson EW, Dietrich WF, Coffin JM (1995b) New seizure frequency QTL and the complex genetics of epilepsy in EL mice. Mamm Genome 6:830-8.

Gershenfeld HK, Paul SM (1997) Mapping quantitative trait loci for fear-like behavior in mice. Genomics 46:1-8.

Gershenfeld HK, Paul SM (1998) Towards a genetics of anxious temperament: from mice to men. Acta Psychiatr Scand 98:56-65.

Gershenfeld HK, Neumann PE, Mathis C, Crawley JN, Li X, Paul SM (1997) Mapping quantitative trait loci for open field behavior in mice. Behav Genet 27:201-210.

Gray JA, NcNaughton N (1996) The neuropsychology of anxiety: reprise. In: Perspectives on anxiety, panic, and fear, vol 43, Nebraska Symposium on Motivation (Hope DA, ed), pp 61-134. Lincoln, NB: University of Nebraska.

Greenberg DA, Delgado-Escueta AV (1993) The chromosome 6p epilepsy locus: exploring mode of inheritance and heterogeneity through linkage analysis. Epilepsia 34:S12-8.

Homanics GE, DeLorey TM, Firestone LL, Quinlan JJ, Handforth A, Harrison NL, Krasowski MD, Rick CE, Korpi ER, Makela R, Brilliant MH, Hagiwara N, Ferguson C, Snyder K, Olsen RW (1997) Mice devoid of gamma-aminobutyrate type A receptor beta3 subunit have epilepsy, cleft palate, and hypersensitive behavior. Proc Natl Acad Sci USA 94:4143-4148.

Im HK, Im WB, Carter DB, McKinley DD (1995) Interaction of betacarboline inverse agonists for the benzodiazepine site with another site on $\mathrm{GABA}_{\mathrm{A}}$ receptors. Br J Pharmacol 114:1040-1044.

Kagan J, Reznick JS, Snidman N (1988) Biological bases of childhood shyness. Science 240:167-171.

Kleinbaum DG (1994) Logistic regression. New York: Springer.

Kosobud AE, Crabbe JC (1990) Genetic correlations among inbred strain sensitivities to convulsions induced by 9 convulsant drugs. Brain Res 526:8-16.

Lambert JJ, Belelli D, Hill-Venning C, Callachan H, Peters JA (1996) Neurosteroid modulation of native and recombinant $\mathrm{GABA}_{\mathrm{A}}$ receptors. Cell Mol Neurobiol 16:155-174.

Lander E, Kruglyak L (1995) Genetic dissection of complex traits: guidelines for interpreting and reporting linkage results. Nat Genet 11:241-247.

Lander ES, Green P, Abrahamson J, Barlow A, Daly MJ, Lincoln SE, Newburg L (1987) MAPMAKER: an interactive package for constructing primary genetic linkage maps of experimental and natural populations. Genomics 1:174-181.

Lawrence MS, Ho DY, Dash R, Sapolsky RM (1995) Herpes simplex virus vectors overexpressing the glucose transporter gene protect against seizure-induced neuron loss. Proc Natl Acad Sci USA 92:7247-7251.

Lin YF, Angelotti TP, Dudek EM, Browning MD, Macdonald RL (1996) Enhancement of recombinant alpha 1 beta 1 gamma $2 \mathrm{~L}$ gammaaminobutyric acidA receptor whole-cell currents by protein kinase $\mathrm{C}$ is mediated through phosphorylation of both beta 1 and gamma $2 \mathrm{~L}$ subunits. Mol Pharmacol 50:185-195.

Lincoln S, Lander ES (1992) Systematic detection of errors in genetic linkage data. Genomics 14::604-610.

Liu AW, Delgado-Escueta AV, Serratosa JM, Alonso ME, Medina MT, Gee MN, Cordova S, Zhao HZ, Spellman JM, Peek JR (1995) Juvenile myoclonic epilepsy locus in chromosome 6p21.2-p11: linkage to convulsions and electroencephalography trait. Am J Hum Genet 57:368-381.

Liu AW, Delgado-Escueta AV, Gee MN, Serratosa JM, Zhang QW, Alonso ME, Medina MT, Cordova S, Zhao HZ, Spellman JM, Donnadieu FR, Peak JR, Treiman LJ, Sparks RS (1996) Juvenile myo- 
clonic epilepsy in chromosome 6p12-p11: locus heterogeneity and recombinations. Am J Med Genet 63:438-446.

Manly KF (1998) User's manual for map manager classic and map manager QT. http://mcbio.med.buffalo.edu/mapmgr.html.

Martin B, Desforges C, Chapouthier G (1991) Comparisons between patterns of convulsions induced by two beta-carbolines in 10 inbred strains of mice. Neurosci Lett 133:73-76.

Martin B, Chapouthier G, Motta R (1992) Analysis of B10.D2 recombinant congenic mouse strains shows that audiogenic and beta-CCMinduced seizures depend on different genetic mechanisms. Epilepsia 33:11-13.

Martin B, Venault P, Chapouthier G (1993) Convulsions induced by methyl beta-carboline-3-carboxylate in mice: effects of preceding saline injections. Epilepsia 34:1003-1006.

Martin B, Marchaland C, Chapouthier G, Motta R (1994) Evidence for a multigenic system controlling methyl-beta-carboline-3-carboxylate (beta-CCM)-induced seizures. Behav Genet 24:285-297.

Martin B, Clement Y, Venault P, Chapouthier G (1995) Mouse chromosomes 4 and 13 are involved in beta-carboline induced seizures. J Hered 86:274-279.

Massotti M, Lucantoni D, Caporali MG, Mele L, Gatta F (1985) Supraspinal convulsions induced by inverse benzodiazepine agonists in rabbits. J Pharmacol Exp Ther 234:274-279.

Mathis C, Paul SM, Crawley JN (1994) Characterization of benzodiazepine-sensitive behaviors in the $\mathrm{A} / \mathrm{J}$ and $\mathrm{C} 57 \mathrm{BL} / 6 \mathrm{~J}$ inbred strains of mice. Behav Genet 24:171-180.

Mathis C, Neumann PE, Gershenfeld H, Paul SM, Crawley JN (1995) Genetic analysis of anxiety-related behaviors and responses to benzodiazepine-related drugs in AXB and BXA recombinant inbred mouse strains. Behav Genet 25:557-568.

McDonald BJ, Moss SJ (1997) Conserved phosphorylation of the intracellular domains of GABA(A) receptor beta 2 and beta3 subunits by cAMP-dependent protein kinase, cGMP-dependent protein kinase protein kinase $\mathrm{C}$ and $\mathrm{Ca} 2+/$ calmodulin type II-dependent protein kinase. Neuropharmacology 36:1377-1385.

McNamara JO (1992) The neurobiological basis of epilepsy. Trends Neurosci 15:357-359.

McNamara JO (1994) Cellular and molecular basis of epilepsy. J Neurosci 14:3413-3425.

Miner LL, Marley RJ (1995) Chromosomal mapping of loci influencing sensitivity to cocaine-induced seizures in BXD recombinant inbred strains of mice. Psychopharmacology 117:62-66.

Neumann PE (1992) Inference in linkage analysis of multifactorial traits using recombinant inbred strains of mice. Behav Genet 22:665-676.

Neumann PE, Collins RL (1991) Genetic dissection of susceptibility to audiogenic seizures in inbred mice. Proc Natl Acad Sci USA 88:5408-5412.

Neumann PE, Collins RL (1992) Confirmation of the influence of a chromosome 7 locus on susceptibility to audiogenic seizures. Mamm Genome 3:250-253.

Neumann PE, Seyfried TN (1990) Mapping of two genes that influence susceptibility to audiogenic seizures in crosses of $\mathrm{C} 57 \mathrm{BL} / 6 \mathrm{~J}$ and DBA/2J mice. Behav Genet 20:307-323.

Neumann PE, Garretson JD, Skabardonis GP, Mueller GG (1993) Genetic analysis of cerebellar folial pattern in crosses of C57BL/6J and DBA/2J inbred mice. Brain Res 619:81-88.

Noebels JL (1996) Targeting epilepsy genes. Neuron 16:241-244.

Nutt DJ, Smith CF, Bennett R, Jackson HC (1992) Investigations on the "set-point" theory of benzodiazepine receptor function. Adv Biochem Psychopharmacol 47:419-429.

O'Connor WM, Davidson BL, Kaplitt MG, Abbey MV, During MJ, Leone P, Langer D, O'Connor MJ, Freese A (1997) Adenovirus vector-mediated gene transfer into human epileptogenic brain slices: prospects for gene therapy in epilepsy. Exp Neurol 148:167-178.

Olsen RW, Avoli M (1997) GABA and epileptogenesis. Epilepsia 38:399-407.
Paterson AH, Damon S, Hewitt JD, Zamir D, Rabinowitch HD, Lincoln SE, Lander ES, Tanksley SD (1991) Mendelian factors underlying quantitative traits in tomato: comparison across species, generations, and environments. Genetics 127:181-197.

Paul SM, Purdy RH (1992) Neuroactive steroids. FASEB J 6:2311-2322.

Polc P (1995) Involvement of endogenous benzodiazepine receptor ligands in brain disorders: therapeutic potential for benzodiazepine antagonists? Med Hypotheses 44:439-446.

Prado de Carvalho LP, Grecksch G, Chapouthier G, Rossier J (1983) Anxiogenic and non-anxiogenic benzodiazepine antagonists. Nature 301:64-66.

Prado de Carvalho L, Grecksch G, Cavalheiro EA, Dodd RH, Chapouthier G, Rossier J (1984) Characterization of convulsions induced by methyl beta-carboline-3-carboxylate in mice. Eur J Pharmacol 103:287-293.

Purdy RH, Moore Jr PH, Morrow AL, Paul SM (1992) Neurosteroids and GABAA receptor function. Adv Biochem Psychopharmacol 47:87-92.

Rise ML, Frankel WN, Coffin JM, Seyfried TN (1991) Genes for epilepsy mapped in the mouse. Science 253:669-673.

Rupprecht R, Hauser CA, Trapp T, Holsboer F (1996) Neurosteroids: molecular mechanisms of action and psychopharmacological significance. J Steroid Biochem Mol Biol 56:163-168.

Sackeim HA, Devanand DP, Prudic J (1991) Stimulus intensity, seizure threshold, and seizure duration: impact on the efficacy and safety of electroconvulsive therapy. Psychiatr Clin North Am 14:803-843.

Sadar MD, Westlind A, Blomstrand F, Andersson TB (1996) Induction of CYP1A1 by GABA receptor ligands. Biochem Biophys Res Commun 229:231-237.

Sander T, Kretz R, Williamson MP, Elmslie FV, Rees M, Hildmann T, Bianchi A, Bauer G, Sailer U, Scaramelli A, Schmitz B, Gardiner RM, Janz D, Beck-Mannagetta G (1997) Linkage analysis between idiopathic generalized epilepsies and the GABA(A) receptor alpha5, beta3 and gamma3 subunit gene cluster on chromosome 15. Acta Neurol Scand 96:1-7.

Schweri MM, Martin JV, Mendelson WB, Barrett JE, Paul SM, Skolnick P (1983a) Pharmacokinetic and pharmacodynamic factors contributing to the convulsant action of beta-carboline-3-carboxylic acid esters. Life Sci 33:1505-1510.

Schweri MM, Paul SM, Skolnick P (1983b) Strain differences in susceptibility to the convulsant actions of 3-carbomethoxy-beta-carboline. Pharmacol Biochem Behav 19:951-955.

Serratosa JM, Delgado-Escueta AV, Medina MT, Zhang Q, Iranmanesh R, Sparkes RS (1996) Clinical and genetic analysis of a large pedigree with juvenile myoclonic epilepsy. Ann Neurol 39:187-195.

Skradski SL, White HS, Ptacek LJ (1998) Genetic mapping of a locus (Mass1) causing audiogenic seizures in mice. Genomics 49:188-192.

Sokal RR, Rohlf FJ (1995) Biometry. New York: W. H. Freeman.

Tunnicicliff G, Raess BU (1991) GABA mechanisms in epilepsy. New York: Wiley-Liss.

Wan Q, Xiong ZG, Man HY, Ackerley CA, Braunton J, Lu WY, Becker LE, MacDonald JF, Wang YT (1997) Recruitment of functional GABA(A) receptors to postsynaptic domains by insulin. Nature 388:686-690.

Wichlinski LJ (1996) Possible involvement of an endogenous benzodiazepine receptor ligand of the inverse agonist type in the regulation of rapid-eye movement (REM) sleep: an hypothesis. Prog Neuropsychopharmacol Biol Psychiatry 20:1-44.

Xiao X, McCown TJ, Li J, Breese GR, Morrow AL, Samulski RJ (1997) Adeno-associated virus (AAV) vector antisense gene transfer in vivo decreases GABA(A) alpha1 containing receptors and increases inferior collicular seizure sensitivity. Brain Res 756:76-83.

Zhang LX, Li XL, Smith MA, Post RM, Han JS (1997) Lipofectinfacilitated transfer of cholecystokinin gene corrects behavioral abnormalities of rats with audiogenic seizures. Neuroscience 77:15-22. 